\title{
Impact of Foreign Direct Investment on Power Sector of Nigeria: 2000-2011
}

\author{
Nwankwo, Odi. \\ Department of Banking and Finance, Kogi State University, Anyigba Kogi-Nigeria \\ Tel: 234-80-3576-3229Ｅ-mail: odinwankwo2002@yahoo.com
}

Received: Jan. 10, 2013 Accepted: February 24, 2013 Published: July 1, 2013

doi:10.5296/jmr.v5i3.3026

URL: http://dx.doi.org/10.5296/jmr.v5i3.3026

\begin{abstract}
Foreign direct investment is increasing in importance in the global economy due to the additional resources they pooled for development in the host country. The objective of this study is to ascertain the impact of foreign direct investment (FDI) on power sector in Nigeria using co-integration test, error correction model and time series data as research design. The result indicated that, most of the variables used were significantly related to the power sector output of the country. From the analysis of our study it was found that Foreign Direct Investment as macro-economic variables as well as openness to trade; infrastructural development; inflationary rate had a significant influence on power sector output in Nigeria. The result has an important implication in terms of policies that will attract foreign direct investment to the power sector of the country. We therefore recommend that, having seen that there is long-run relationship between foreign direct investment (FDI) inflow and power sector output in Nigeria and FDI in Nigeria induces the nation's power sector growth. There is need to encourage FDI in Nigerian power sector and since FDI has the highest potential for contributing growth, it needs to be properly channeled and integrated into the mainstream of the nation's power sector.
\end{abstract}

Keywords: Power Sector, FDI, FDI inward, FDI outward, Net FDI, Openness to trade 


\section{Introduction}

Foreign direct investment is increasing in importance in the global economy due to the additional resources they pooled for development in the host country. They have also attracted great controversy concerning their positive or negative contributions to economic development of the host country. In recent years, foreign direct investment (FDI) has attracted renewed interest both in the underdeveloped and developed countries. Foreign direct investment (FDI) plays a major role in global business. FDI can provide a firm with new markets and marketing channels, cheaper production facilities, access to new technology, products, skills and financing. For a host country or the foreign firm which receives the investment, it can provide a source of new technologies, capital, processes, products, organizational technologies and management skills, and as such can provide a strong impetus to economic growth (Raul, 2012).

The most widely accepted definition of FDI is known as "the IMF/OECD (2011) benchmark definition" which states that foreign direct investment (FDI) is an international venture in which an investor residing in the home economy acquires a long-term "influence" in the management of an affiliate firm in the host economy. This definition is accepted because it was provided by a joint workforce of these two international organizations with the objective of providing standards to national statistical offices for compiling FDI statistics. Based on the definition, the existence of such long-term influence should be assumed when voting shares or rights controlled by the multinational firm amount to at least 10 percent of total voting shares of rights of the foreign firm. Aggregate FDI flows are the sum of equity capital, reinvested earnings, and other direct investment capital; hence, aggregate FDI flows and stocks include all financial transfers aimed at financing of new investments, plus retained earnings of affiliates, internal loans, and financing of cross-border mergers and acquisitions. FDI flows can be observed from the perspective of the host economy, which records them as inward FDI along with other liabilities in the balance of payments, or from the perspective of the home economy, which records them as outward FDI, a category of assets. FDI may take many forms, such as a direct acquisition of a foreign firm, construction of a facility, or investment in a joint venture or strategic alliance with a local firm with attendant input of technology, licensing of intellectual property.

In Nigeria and other countries in Sub-Saharan Africa, the provision of low-cost, affordable and regular electricity supply is critical to employment generation, poverty alleviation and industrial development especially in small scale industry. Though Nigeria is energy surplus in theory not in practical given the range of energy options in the country; it has been unable to translate its energy abundance into socio-economic development due largely to the policy environment and the nature of institutions put in place to drive activities in the energy sector. To this extent, socio-economic development of Nigeria through power sector is still enmeshed in the nightmare of "darkness" occasioned by epileptic electric power generation and distribution. The low performance of the electric power sector of Nigeria and other West African countries created the inevitable need for collaboration under the West African Power Pool Project (WAPPP) (Gnansonuou, 2008). 
Since the first production of electricity in Nigeria in 1896, the electricity sector has gone through a number of reforms but is yet to achieve effective and reliable supply of electricity. The present reform embarked on took a new dimension with the government shifting from its monopoly over the power sector in Nigeria to inviting private sector participation with the intent of eventual divestiture to the private sector either by concession, privatization or management contracts. In furtherance to this, the Bureau of Public Enterprises (BPE) with the authority to prepare public enterprises approved by the National Council on Privatization (NCP) for privatization and commercialization has commenced the privatization exercise. The Power Holding Corporation of Nigeria (PHCN) has since been unbundled to 18 successor companies and the Nigerian Electricity Regulatory Commission (NERC) has been established to ensure the orderly development of a competitive power market, safe and adequate production of electricity and to promote competitive private sector participation (Oke, 2012).

Nigerian's success in attracting FDI into the power sector will have importance beyond reducing shortages and enhancing productivity in the country. Nigeria is one of the world's leading sources of generating electricity and its power sector is responsible for distribution of electricity in the country (Battle, 2009). Hence, to the extent that FDI can enhance the energy efficiency of Nigeria plants.

There is consensus among governments of industrialized and non industrialized countries like Nigeria that foreign direct investment may be desirable for economic growth and poverty reduction. Many questions remain about how foreign investment can enhance the economics of the recipient or the host country. Kiely (2007) summarizes some of the arguments for and against Transnational Corporations and the capital investment they bring. Critics of foreign investment have suggested that it led to dependent, or restricted, development. To them, FDI may lower domestic savings and investments rates by stiffing competition through exclusive production agreements with host Governments and failing to reinvest most of the profits. Supporters have suggested that foreign investment can bring capital and technology, develop skills and linkages and increased employment and incomes. Focusing on the positive side of the argument, government of Nigeria in an attempt to achieve the efficient, stability and growth process of the power sector has issued some incentives to attract foreign capital in her economy. The issue of Foreign Direct Investment (FDI) as it affects power sector is one of the most disputed areas in international economies. This is an account of the need for a steady growth in power sector across international economies. The growth of literature on the subject also has significant bearing on the underlying problems of capital inflow, openness to trade, policy framework, balance of payment deficit and inflation (Odozi, 1995; Oyinlola, 1995; Adelegan, 2000; Akinlo, 2004).

The aim of this paper is to empirically ascertain impact of FDI on Power Sector performance in Nigeria. This paper is organized as follows; section one is the introduction while section two reviews the empirical and theoretical literature on agricultural financing; section three discusses the models and methodology while section four provides data and empirical evidence and the final section which is section five provides the summary, conclusion and recommendations of the study. 


\section{Review of Related Literature}

\subsection{Empirical Review}

There has not been extensive theoretical and empirical research examining the impact of foreign direct investment on power sector performance in both developed and underdeveloped countries. Thus far, the academic literature describing FDI in Nigerian's power sector has been thin or none. The literature that does exist does not include detailed information on foreign investors' perceptions of the investment climate, on the volume and characteristics of FDI, or on the energy efficiency of FDI plants. This paper attempts to fill this gap by using data from a variety of sources. Mojekwu and Samson (2012) used co-integration and error correction model to examine the relationship between foreign direct investment and the challenges of sustainable development in Nigeria. The study revealed that there exist a long-run relationship between the dependent variable and explanatory variables and that gross capital formation has a positive and significant relationship with the economic growth in Nigeria. Based, on the findings, they therefore, recommended that capital formation encourages economic growth via savings accumulation visa vise, increase in the gross domestic investment. Also, there is need for constructive attention to be given to provision of needed infrastructure, especially power generation and distribution, to enhance economic growth and development.

Opaluwa, Ameh, Alabi and Abdul (2012) conducted research on the effect of foreign direct investment on the Nigerian manufacturing sector using Vector Auto Regression (VAR), co-integration and error correction techniques to establish the relationship between FDI and the growth of manufacturing sector. The findings from the study shows that FDI has a negative effect on the manufacturing productivity and is statistically significant. Arising from the findings, they recommended that government should create an enabling environment for foreign investment and the monitoring of FDI benefits, with particular focus of NEPAD and NEEDS through the instrumentality of the MDGs; thereby mustering the capacity for sustainable growth in the manufacturing sector. Ogbanje, Okwu and Saror (2010) in a study of an analysing the impact of foreign direct investment on Nigeria's agricultural sector using Duncan Multiple Range Test and Ordinary least square. The result shows that the relationship between foreign direct investment (FDI) to agricultural sector and agricultural gross domestic product (GDP) was significant at 0.01 level of probability. They conclude that net flow of FDI to Nigeria discriminates against the agricultural sector.

\subsection{Theoretical Framework}

In an attempt to capture the true insight of the place of FDI inflow in Nigerian's power sector, we reviewed critically three theories associated with FDI. These theories were discussed below:

\subsubsection{The Endogenous Growth Theory}

In economics, endogenous growth theory or new growth theory was developed in the 1980 as a response to criticism of the neo-classical growth model. The endogenous growth theory holds that policy measures can have an impact on the long-run growth rate of an economy. For 
example, subsidies on research and development or education increase the growth rate in some endogenous growth models by increasing the incentive to innovate. Endogenous growth theory tries to overcome this shortcoming by building macroeconomic models out of microeconomic foundations. Households are assumed to maximize utility subject to budget constraints while firms maximize profits. Crucial importance is usually given to the production of new technologies and human capital. The engine for growth can be as simple as a constant return to scale production function (the AK model or more complicated set ups with spillover effects (spillovers are positive externalities, benefits that are attributed to costs from other firms), increasing numbers of goods, increasing qualities, etc.

Often endogenous growth theory assumes constant marginal product of capital at the aggregate level, or at least that the limit of the marginal product of capital does not tend towards zero. This does not imply that larger firms will be more productive than small ones, because at the firm level the marginal product of capital is still diminishing. Therefore, it is possible to construct endogenous growth models with perfect competition. However, in many endogenous growth models the assumption of perfect competition is relaxed, and some degree of monopoly power is thought to exist. Generally monopoly power in these models comes from the holding of patents. The main implication of recent growth theory is that policies which embrace openness, competition, change and innovation will promote growth. Conversely, policies which have the effect of restricting or slowing change by protecting or favoring particular industries or firms are likely over time to slow growth to the disadvantage of the community. This theory was useful in this research considering the fact that it tackles the issue of Spill over and growth. Specifically, like FDI in the twentieth century the Endogenous growth model is aimed to address the issue of Spillover effect and growth in any prominent Economy (Adeolu, 2007).

\subsubsection{Industrialization Theory on FDI and Spillover Effects}

Hymer's (1976) pioneering study on multinational companies (MNCs) drew attention to neglected aspects of MNCs' role as global industrial organizations. Hymer's view was a major departure from the orthodox theoretical economic literature. The standard neoclassical trade theory of Heckscher and Ohlin, for example, carried restrictive assumptions about the immobility of factors of production and identical production functions across national boundaries. It postulated that no international difference existed at the scientific and technological levels, not to mention technology transfer and spillovers. In the neoclassical financial theory of portfolio flows, multinational enterprises had been viewed as simply an arbitrageur of capital in response to changes in interest rate differentials. Capital is seen to flow from countries where returns are low to those where it is higher to earn arbitrage rents. This theory did not distinguish between the roles played in a country's development by portfolio and FDI capital inflows. Hymer's major contribution was to shift attention away from neoclassical financial theory. In his view, FDI is more than a process by which assets are exchanged internationally. It also involves international production. By putting forward the idea that FDI represents not simply a transfer of capital, but the transfer of a "package" in which capital, management, and new technology are all combined, Hymer characterized FDI as an international extension of industrial organization theory. 


\subsubsection{Two-Gap Model (2GM)}

This model which expands out of the adaptation of Harrod- Domar growth hypothesis to the open economy by planners is interested in exports, imports, savings, investment and foreign aid. This two-gap comprises of the foreign exchange gap and the domestic savings gap. Hollis and others concur that domestic savings and foreign exchange gaps are separate and have independent constraints towards achieving growth in the LDCs. To fill these gaps, Chenery (1996) sees its actions to source for foreign aid in order to achieve economy's target growth rate. He further postulates a fixed relationship between targeted foreign exchange requirement and net export earnings. If the latter fall short of the former, a foreign exchange gap prevails; this can be obviated by foreign aid. To explain this phenomenon, the national income accounting identity is employed thus: $\mathrm{E}=\mathrm{Y}=\mathrm{I}-\mathrm{S}=\mathrm{M}-\mathrm{X}=\mathrm{F}$

Where; $\mathrm{E}=$ National Expenditure $=$ National Output or Income, $\mathrm{I}=$ Investment, $\mathrm{S}=$ Savings, $\mathrm{M}=$ Import,$\quad \mathrm{X}=$ Export and $\mathrm{F}=$ Capital inflow.

Therefore, an economy is said to be in a foreign exchange gap or savings constraints depending on the most prevailing one. However, foreign aid eliminates foreign exchange gap by allowing new investment project, importing plant and machineries, technical assistance and intermediate goods. In the long run, the foreign aid required equals the difference between increase in investment and savings increase caused by increasing income. The elimination of savings gap brings about sustained growth rate. The vital issue is how beneficial or detrimental foreign aid is to the growth of LDCs. Appropriate utilization of foreign aid enhances rapid growth of a debtor country. This reflects through increase in investment level at a faster rate than it could otherwise have been, if the source of investible funds were to be domestic savings of the recipient country. Also, the size of the rate of investment increases depending on the assumed savings function. On the other hand, foreign loan could be detrimental if it is spent on unproductive investment like political campaign, buying and maintenance of luxuries cars, houses etc at the expenses of necessities and consumption not likely to raise enough funds for debt servicing.

\subsection{Concept of Foreign Direct Investment}

Foreign direct investment (FDI) is a measure of foreign ownership of productive assets, such as factories, mines and land. Increasing foreign investment can be used as one measure of growing economic globalization (Haman, 2008).

In the past ten years, the classic definition of FDI as noted above has changed considerably. This notion of a change in the classic definition, however, must be kept in the proper context. Very clearly, over two third of direct foreign investment is still made in the form of fixtures, machinery, equipment and buildings. Moreover, larger multinational corporations and conglomerates still make the overwhelming percentage of FDI. But, with the advent of the Internet, the increasing role of technology, loosening of direct investment restrictions in many markets and decreasing communication costs means that newer, non-traditional forms of investment will play an important role in the future. Many governments, especially in industrialized and developing nations such as Cameroon, pay very close attention to foreign 
direct investment because they believe that investment flows into (Inward FDI)and out(Outward FDI) of their economies may have a significant impact (Aseidu, 2009).

Within the past ten years, however, there has been a dramatic increase in the number of technology startups and this, together with the rise in prominence of Internet usage, has fostered increasing changes in foreign investment patterns. Many of these high tech startups are very small companies that have grown out of research and development projects often affiliated with major universities and with some government sponsorship. Unlike traditional manufacturers, many of these companies do not require huge manufacturing plants and immense warehouses to store inventory (Aseidu, 2004).

Another factor to consider is the number of companies whose primary product is an intellectual property right such as a software program or a software-based technology or process. Companies such as these can be housed almost anywhere and therefore making a capital investment in them does not require huge outlays for fixtures, machinery and plants. In many cases, large companies still play a dominant role in investment activities in small, high tech oriented companies (Andreas, 2007). However, unlike in the past, these larger companies are not necessarily acquiring smaller companies outright. There are several reasons for this, but the most important one is most likely the risk associated with such high tech ventures. In the case of mature industries, the products are well defined. The manufacturer usually wants to get closer to its foreign market or wants to circumvent some trade barriers by making a direct foreign investment. The major risk here is that we do not sell enough of the product that we manufactured. However, we have added additional capacity and in the case of multinational corporations this capacity can be used in a variety of ways. High tech ventures tend to have longer incubation periods. That is, the product tends to require significant development time. In the case of software and other intellectual property type products, the product is constantly changing even before it hits the marketplace. This makes the investment decision more complicated. When we invest in fixtures and machinery, we know what the real and book value of our investment will be. When we invest in a high tech venture, there is always an element of uncertainty (Bengos and Sanchez-Robles, 2008).

Therefore, the expanded role of technology and intellectual property has changed the foreign direct investment playing field. Companies are still motivated to make foreign investments, but because of the vagaries of technology investments, they are now finding new vehicles to accomplish their goals. Consider the following:

Licensing and technology transfer: Licensing and technology transfer have been essential in promoting collaboration between the academic and business communities. Ever since legal hurdles were removed that allowed universities to hold title to research and development done in their labs, licensing agreements have helped turned raw technology into finished products that are viable in competitive marketplaces. With some help from a variety of government agencies in the form of grants for research and development as well as other financial assistance for such things as incubator programs, once timid college researchers are now stepping out and becoming cutting edge entrepreneurs. These strategic alliances have had a serious impact in several high tech industries, including but not limited to: medical and 
agricultural biotechnology, computer software engineering, telecommunications, advanced materials processing, ceramics, thin materials processing, photonics, digital multimedia production and publishing, optics and imaging and robotics and automation.

Licensing agreements allow companies to take full advantage of new and exciting technologies while limiting their overall risk to royalty payments until a particular technology is fully developed and thus ready to put new products into the manufacturing pipeline.

Reciprocal distribution agreements: Actually, this type of strategic alliance is more trade-based, but in a very real sense it does in fact represent a type of direct investment. Basically, two companies, usually within the same or affiliated industries, agree to act as a national distributor for each other's products. The classical example is to be found in the furniture industry.

Joint venture and other hybrid strategic alliances: The more traditional joint venture is bi-lateral, that is it involves two parties who are within the same industry who are partnering for some strategic advantage. Typical reasons might include a need for access to proprietary technology that might tip the competitive edge in another competitor's favor, desire to gain access to intellectual capital in the form of ultra-expensive human resources, access to heretofore closed channels of distribution in key regions of the world. One very good reason why many joint ventures only involve two parties is the difficulty in integrating different corporate cultures. With two domestic companies from the same country, it would still be very difficult. However, with two companies from different cultures, it is almost impossible at times. This is probably why pure joint ventures have a fairly high failure rate only five years after inception. Joint ventures involving three or more parties are usually called syndicates and are most often formed for specific projects such as large construction or public works projects that might involve a wide variety of expertise and resources for successful completion. In some cases, syndicates are actually easier to manage because the project itself sets certain limits on each party and close cooperation is not always a prerequisite for ultimate success of the endeavor.

Feldstein (2008) stated that, foreign investment allows companies to accomplish several tasks like: Avoiding foreign government pressure for local production; Circumventing trade barriers, hidden and otherwise making the move from domestic export sales to a locally-based national sales office; Capability to increase total capacity; Opportunities for co-production, joint ventures with local partners, joint marketing arrangements, licensing, amongst others.

A more complete response might address the issue of global business partnering in very general terms. While it is nice that many business writers like the expression, "think globally, act locally", this often used cliché does not really mean very much to the average business executive in a small and medium sized company. The phrase does have significant connotations for multinational corporations. But for executives in SME's, it is still just another buzzword. The simple explanation for this is the difference in perspective between executives of multinational corporations and small and medium sized companies. Multinational corporations are almost always concerned with worldwide manufacturing 
capacity and proximity to major markets. Small and medium sized companies tend to be more concerned with selling their products in overseas markets. The advent of the Internet has ushered in a new and very different mindset that tends to focus more on access issues. SME's in particular are now focusing on access to markets, access to expertise and most of all access to technology.

Depending on the industry sector and type of business, a foreign direct investment may be an attractive and viable option. With rapid globalization of many industries and vertical integration rapidly taking place on a global level, at a minimum a firm needs to keep abreast of global trends in their industry. From a competitive standpoint, it is important to be aware of whether a company's competitors are expanding into a foreign market and how they are doing that. At the same time, it also becomes important to monitor how globalization is affecting domestic clients. Often, it becomes imperative to follow the expansion of key clients overseas if an active business relationship is to be maintained.

New market access: It is also another major reason to invest in a foreign country. At some stage, export of product or service reaches a critical mass of amount and cost where foreign production or location begins to be more cost effective. Any decision on investing is thus a combination of a number of key factors including: assessment of internal resources, market analysis, competitiveness, market expectation.

\subsection{Principles of Foreign Direct Investment}

A study presented by David (2008) states that investment recipient countries should adopt a code of conduct that embodies the following four principles.

Principle1: The investment review law should be narrowly tailored and focused on national security and not on economic factors.

One of the fundamental principles of international trade and investment agreements over the past fifty years around the world is that any restrictions should be the least that are needed to achieve the government's objective. This principle should apply today to the new foreign investment regimes being debated and enacted. Government restrictions on foreign investment should be limited to those problems that the market itself cannot prevent, such as anticompetitive impacts or threats to national security. Governments should refrain, however, from reviewing transactions for their economic, as opposed to national security, impacts because such inquiries could easily devolve into actions to restrict investment for protectionist reasons. China's new regulations authorize reviews of foreign investments based on principles of economic security. Canada's new guidelines for foreign investments by state-owned enterprises include consideration of, among other things, the investor's plans with respect to exports, manufacturing, and capital expenditures. Again, unless national security, competition, or some other market failure is addressed, these decisions should be left to investors, not governments. This is important because investors make decisions based on the prospect of risk-adjusted returns. If the assessed risk increases, so must the projected returns. Government scrutiny of investments by definition raises risk, and therefore if governments unnecessarily get involved in reviewing investments, investment flows could 
diminish. To be clear, this is in no way to argue that governments should not protect legitimate interests, including national security.

Rather, investment review laws should be as narrowly tailored as possible in order to avoid chilling investment in transactions that do not raise national security or other governmental interests.

Principle 2: The investment review process should provide predictability to transaction parties by ensuring that reviews will be conducted within a definite timeframe. With the exception of price, few other factors are more important for investors than the speed with which a transaction can close. Investors frown on uncertainty, and the longer a transaction takes to close, the greater the uncertainty. In the time between the signing and closing of a transaction, business fundamentals could change, senior executives could depart, and competitors could introduce new products and services. Thus, in order to avoid chilling investment, foreign-investment review mechanisms should include short and defined time periods during which the investor is guaranteed to receive a decision from the government. In the United States, most reviews are completed in thirty days, with the possibility for CFIUS to take another sixty days for the more difficult cases.

The proposed new Russian law contemplates ninety-day reviews for most transactions with the possibility of additional time for complex investments, creating the potential for lengthy delays before deals can be completed. The draft German regulations have been criticized because the government similarly has up to three months to act, creating uncertainty during those ninety days. Based on discussions with government officials, lawyers, and investment advisers, most transactions filed with authorities do not raise complex national security issues. In general, therefore, review mechanisms should be designed to facilitate reviews of most transactions in a very short period of time say thirty days while giving governments additional time to review transactions that raise novel or particular complex national security issues.

Principle 3: The investment review process should ensure confidentiality to the transaction parties. Strict confidentiality within an investment review mechanism is essential to create confidence that data and information provided to governments will be protected from the public and competitors. Investment review authorities frequently ask for inventors' plans, customer lists, and personnel and technical information. It is critical to ensure parties have confidence in the government and its regulatory mechanisms and can trust that confidential business and proprietary information will not be compromised. Furthermore, given the nature of national security based investment reviews, confidentiality is imperative to preserve the interests of the government.

\subsection{Some Policies Guiding Foreign Direct Investment Policies around the World}

David (2009) stated that in the twentieth century United States Congress passed many laws that either restricted foreign investment in certain sectors (including shipping, broadcasting, and air services) or that gave the president the authority to block or seize certain foreign investments. More specifically, Congress passed the Trading with the Enemy Act (TWEA) in 
1917, which was used by presidents to expropriate German, and even some non-German chemical and broadcasting assets in the United States, including American Marconi, the largest radio group in the United States at the time, which was controlled by British interests. In 1977, Congress passed the International Emergency Economic Powers Act (IEEPA), the successor to TWEA, which has been utilized by presidents for a variety of national security-related actions affecting trade and investment. And in 1988, in response to concern about growing levels of Japanese investment in the United States, Congress passed the Exon-Florio amendment to the Defense Production Act of 1950, giving the president the specific authority to block individual acquisitions by foreign entities without declaring an emergency under IEEPA.

Notwithstanding these laws and regulations, and similar laws and regulations in other countries, the last twenty-five years have seen the gradual liberalization of foreign investment regimes. Europe, the United States, and other industrialized countries each took major steps to encourage FDI in the 1990 s, opening up certain sectors that were previously highly restricted, including telecommunications, as a result of the Uruguay Round and associated trade agreements. Liberalization has been particularly pronounced in developing countries, which have recently become important sources and destinations for FDI. China, for example, has been one of the largest recipients of FDI since 2000, a remarkable and positive change after decades of walling off its economy to foreign investment and trade.

India, Brazil, Russia, and dozens of smaller developing countries as Nigeria have also made substantial strides in opening up their economies to FDI. As a result, even with the natural ups and downs associated with global growth cycles, FDI has grown dramatically in the past generation.

In the past few years, however, the trend toward liberalizing policy actions has either slowed or reversed. (UNCTAD, 2005) reported the highest number of "unfavorable" (investment-restrictive) policy actions since it began tracking many years ago: 41 of 205 total actions. To be sure, "favorable" (investment-liberalizing) actions still far outnumbered "unfavorable" actions, but the number of restrictive actions increased dramatically. The share of unfavorable actions was even higher in 2006: 20.1 percent of the total (37 of 184 actions).

After a debate of nearly eighteen months, in 2007 the United States Congress passed the Foreign Investment and National Security Act (FINSA), which amended the Exxon-Florio amendment to the Defense Production Act. Exxon-Florio empowers the president to block the foreign acquisition of a U.S. company if it threatens to impair U.S. national security and if no other laws or regulations adequately protect national security. The 2007 law creates a formal statutory basis for the Committee on Foreign Investment in the United States (CFIUS) to review such acquisitions. CFIUS, an interagency body led by the Department of the Treasury, was created in 1975 to monitor foreign investment in the United States and was given authority to formally review investments in 1988. The 2007 law also requires heightened scrutiny of acquisitions by government-owned companies, mandates the involvement of high-level officials in CFIUS, and requires additional reporting to Congress. The law, however, is not a radical departure from the original Exxon-Florio amendment. It does not 
change the time periods for the review; it does not give Congress the explicit right to override decisions by the executive branch; and it does not ban or even discriminate against foreign investment in certain sectors of the U.S. economy.

\subsection{The Power Sector Reforms in Nigeria}

The Nigerian state is characterized by a confluence of factors. On the one hand economic interests, political forces, capitalists' entities and other bureaucratic institutions determine the political, economic, social and other laws or policies suitable or adoptable for the Nigerian state per time. The same situation manifests vividly in the electricity sector of Nigeria, which led to the current reform in the sector. The nature of the electricity industry has led to the wave of new regulatory regimes across the globe. A good number of developed countries have unbundled their electricity industries by separating generation from transmission. The private sector now dominates generation as in the case of England and Wales. ${ }^{1}$ These models have also been implemented in a number of countries across the globe like Chile, Argentina, Bolivia, Ecuador, Thailand, China and lately Senegal, Uganda and Nigeria.

In Nigeria, electricity supply relies significantly on hydropower. This is also the case in Ghana, Benin, Togo, Guinea and Mali. Electricity supplies have been less than satisfactory in these countries due to frequent outages. The situation is same in Senegal where electricity generation is mainly based on oil, as the country have experienced frequent power plant outages due to low reliability and difficulty of fuel procurement. One would expect that Nigeria, being a major oil producer and exporter coupled with its gas potentials, would enjoy relatively stable electricity generation and distribution for its huge population and sizable industry compared to other West African countries highlighted above. As a matter of fact, the story in Nigeria is gloomier than the other countries mentioned leading to the reforms embarked upon by the Nigerian government in the electricity sector.

Under the new regime, the Nigerian Electricity Regulatory Commission (NERC) is to serve as the main regulatory body of the reformed electric power sector. The responsibilities of NERC include licensing of successor power companies, establishment of electricity tariffs, enforcement of performance standards, and the protection of consumer rights. The existence of NERC is brought about by the Electric Power Sector Reform Act. The Act repeals and replaces the NEPA and Electricity Act. It also removes the operational and regulatory responsibilities of the electric power sector from the Federal Republic of Nigeria and provides the legal bases for restructuring NEPA and establishing of new regulatory structures. The Act establishes three regulatory institutions, namely the National Electricity Regulatory Commission (NERC) which serves as the main regulatory body; the Rural Electrification Fund (REF), and the Consumer Assistance Funds. By these reforms, the monopoly hitherto enjoyed by erstwhile National Electric Power Authority (NEPA) for several decades has been abrogated, as the new regime aims to liberalize the sector. However, despite nomenclature shift from NEPA to Power Holding Company of Nigeria ( $\mathrm{PHCN}$ ), the problem of declining electricity generation from domestic power plants still persists due to dilapidated structures, obsolete equipment among others. While the Nigerian electricity sector is agreeably 
liberalized, the sector has witnessed series of disinvestment from the private sector and collapsed of deal talks with potential private electricity services provider. The masses, as end users of the current wobbly electricity have remained tirelessly hopeful for a new dawn, even in the midst of unfulfilled promise of declaration of national emergency in the power sector, which the current administration promised at its inception.

Energy as a prerequisite for economic growth and development is widely acknowledged by energy experts and scholars. In terms of theory, energy has been shown to be equally as important as other factors of production such as land, labour and capital because of its significance to economic growth. The availability of viable energy options like low-cost electricity, renewable and alternative energies and others are indispensable to socio-economic development in Nigeria. The demand for better electricity and its centrality to national growth and economic development created the ineluctable need for the reforms in Nigeria's electricity sector. However, the rate of growth and development of the sector have been less than impressive despite these reforms. This underscores the need for rethinking the current law and policy frameworks in the Nigerian electricity sector with a view to determining the reason for the seemingly intractable nature of the problems of the electricity sector.

\subsection{Decentralized Energy Options}

The concept of "Decentralized Energy Options [DEOPs]" centers on holistic approach to sustainable energy policy for the developing countries. It advocates decentralization of the governance structure, multiplication of the means of production, availability of affordable options and devolution of governance, control and management responsibilities. One major problem with the regulatory and governance frameworks of electricity in Nigeria and other countries in Sub-Saharan Africa is over-centralization of management responsibilities and administrative structures. Adoption of decentralized governance models have helped in repositioning the energy and natural resources sectors of several countries world over. The driving force varies from one country to another. In countries such as Kenya, United Kingdom and in Latin America, privatization of electricity has provided a means of attracting funds from the private sector to relieve the burden of inadequate government funding or subsidy in the power sector. Prior to the reforms, funding of the power sector has been centralized through a top-down funnel structure from the Federal Government like in Kenya and Nigeria. The reform process in Kenya brought about a policy shift that aligns with the general trend of privatization and decentralization in the energy and other sectors to attract foreign capital and increase competition. However, in the case of Nigeria, while emphasis is placed on the need to liberalize the sector to stimulate private sector involvement; the governance structures and institutions put in place to manage the process would appear inadequate or improperly positioned to achieve desired objectives compared with Kenya. In Kenya for example, the widespread introduction and adoption of renewable energy technologies is made national priority on virtually every national development policy agenda. No similar policy exists in Nigeria because the electricity regime in the country seems to place strong emphasis on revamping the old order under the defunct NEPA under the new PHCN and the regulatory frameworks provided by the NERC (Oke, 2011). The benefits of renewable energy and decentralized energy options have neither been articulated nor 
maximized in the current electricity regime in Nigeria unlike in other countries.

The availability of renewable energies or alternatives is vital to the provision of low-cost, affordable and regular electricity for industrial development, employment generation and poverty alleviation in Nigeria and other the developing countries in Sub-Saharan African. Renewable energies are a means of decentralizing the available energy sources or options in the country. If vigorously embarked upon, it would help Nigeria create the much-desired national energy sufficiency as well promote positive environmental consciousness and values. The 1999 Constitution of the Federal Republic of Nigeria places electricity generation, transmission and distribution on the Concurrent Legislative List to enable all tiers of government to be involved in vital aspects of the electricity industry. The reality of electricity regulation in Nigeria clearly depicts the opposite. The Renewable Electricity Policy of the Federal Government of Nigeria (Renewable Energy Policy) 2006 merely acknowledges that "renewable electricity offers cost effective, modular and decentralized options for extending electricity and stimulating sustainable development in rural areas". The Federal Government of Nigeria hopes to "develop innovative, cost-effective and practical measures to accelerate access to electricity services in rural areas through renewable sources". The strategy of the Federal Government in this regard does not involve direct engagement with the local people through their respective Local Governments Councils. For the renewable policy to be effective, the imperative of decentralized, participatory energy strategy like DEOPS cannot be overemphasized (Electricity Policy of the Federal Government of Nigeria, 2006).

\subsection{Decentralized Electricity Financing}

Sustainable energy might be difficult to attain if the funding mechanism of the new electricity regime in Nigeria is not wholly liberalized and diversified. This is because energy projects generally have high initial costs. Without adequate financial incentives, investing in the electricity sector in Nigeria might be difficult. The lack of capacity of Nigeria in the area of manufacturing components of renewable energy technologies also adds to the incremental cost of electricity generation and distribution in the country. Some electricity projects are better located in the remote areas thus posing significant challenges in terms of attracting competent and qualified manpower for operations. Adoption of decentralized electricity governance model would make for participatory, all-inclusive regime that makes it possible to integrate and engage the services or labour of trained local people closest to the projects.

Financing is crucial to realizing the Federal Government's electricity policy. In funding electricity, the Nigerian government has put in place a number of mechanisms including the Renewable Electricity Trust Fund, which aims to promote, support and provide renewable electricity through private and public sector participation. Other sources of financing include equity, debt financing, grants and micro finance in addition to private funding by way of Independent Power Project (IPP) investment in the electricity sector in Nigeria. The funding mechanisms of the new regime appear decentralized, representing a good mix for maximizing financing alternatives due to cost intensiveness and dynamism of the electricity sector. 
Availability of investing funds is central to the objective of the reformed energy sector in Nigeria. The global demand for infrastructure has dragged project financing from its hitherto restrictive arenas of mining and rail development in the medieval ages to new sectors like electricity generation and transmission, oil and gas, pipelines, telecommunications, transportation and even more in the emerging markets of Nigeria and elsewhere. However, commercial realities dictate that in making energy and natural resources investment project bankability will remain a major consideration. This is because, according to a scholar, the process of making investment decisions is as much idiosyncratic as it is scientific. There are no absolute or universal standards of legal adequacy for foreign investment in the energy sector, as it is always a question of what will satisfy a particular investor and whether the project will satisfy the requirement of "bankability". Financing for the repacked power sector of Nigeria is best attained through "project finance or limited recourse financing model because in case of default, recourse is had to the project or the project vehicle to recoup funds. This recourse mechanism of project financing is decentralized, that is, no direct recourse to the borrowers. This model attunes with the DEOPs principle making it attractive as a suitable funding model for the reformed electricity sector in Nigeria.

Electricity is a capital intensive adventure and to attract investment financing in a country like Nigeria entails certain idiosyncratic and factual issues given Nigeria's background and standing in the energy sector. In the quest for improved electricity generation and distribution, it must be well understood by the Nigerian government, potential investors and other stakeholders that a number of socio-political considerations would likewise determine the suitability or otherwise of making investment commitments in electricity sector. Generally, the investment atmosphere must be such as is able to instill unflinching confidence in the investors that recouping the invested capital with competitive yields would not in any way be clogged. The several issues involved are generally referred to as bankability - a technical term denoting commercial expectations and assurances that an investor will recoup investment capital with freely transferable, attractive gains. Regardless of theoretical assumptions in principles like "pollution haven", "regulatory chill", the "race-to-the-bottom" theory, and other phenomena associated with competition, attracting foreign direct investment (FDI) in Nigeria is one of the focal aims of the power sector reforms in Nigeria.

\section{Econometric Models}

\subsection{Research Design}

Based on the nature of this work and method adopted by Ogbanje, Okwu and Saror (2010); Mojekwu and Samson (2012); and Opaluwa, Ameh, Alabi and Abdul (2012), the study adopted co-integration test which examines the existence of long-run relationship between foreign direct investment and power sector in Nigeria and Error Correction Model (ECM) which determine the short term dynamics to determine the direction of errors between dependent and independent variables. To incorporate foreign direct investment (FDI) and its impact on the growth of Nigerian power sector, the dependent variable is power sector output in Nigeria (PSO) while independent variables used are Net Foreign Direct Investment (FDI), Foreign Direct Investment Inward, Foreign Direct Investment Outward, Openness of the 


\section{Macrothink}

Journal of Management Research

ISSN 1941-899X

2013, Vol. 5, No. 3

Economy (OPEN), Infrastructural development; and finally the rate of inflation. The data covers the period from 2000 to 2011.

\subsection{Model Specification}

The model used by Mojekwu and Samson (2012) was adopted and re-specified to capture the objectives of our study. To capture the objective of this study, the equation below was re-specified.

PSO = f(NFDI;INFDI;OUTFDI;OPEN,INFRA,INFL )... (1).

Specifically, given the time series nature of the data available, the postulated long-run model became:

GDPPCAP $=\beta_{0}+\beta_{1 \text { net }}$ FDI flow $+\beta_{2}$ OPEN $+\beta_{3}$ FDI inward $+\beta_{4}$ FDIoutward $+\beta_{5}$ $I N F R A+\beta_{6} I N F L+U_{t} \ldots(2)$

Where;

$P S O=$ Power Sector Output

$N F D I=$ Net foreign direct investment flow

OUT FDI =Foreign direct investment outward

$I N F D I=$ Foreign direct investment inward

$O P E N=$ openness of the economy

$\mathrm{INFR}=$ is the infrastructural development

$\mathrm{INFL}=$ is the rate of inflation

$\beta_{o}$ is the regression constant

$\beta_{1,} \beta_{2}, \beta_{3}, \beta_{4}, \beta_{5}$ are the parameters coefficients of the variables and all positive

$\beta_{6}, \quad<0$

$U t$ is the stochastic disturbance term.

Thus, transforming equation (2) to the natural logarithm, we obtain:

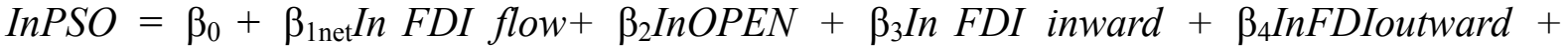
$\beta 5 \operatorname{InINFRA}+\beta 6$ InINFL $L_{+} U_{t} \ldots$ (3)

Where;

InPSO is the natural logarithm of the dependent variable, and InNFFDI, InOPEN, - - InINFL are the natural logarithm of the independent variables. Thus, the transformed $\log$ linear equation (3) was estimated using unit roots test for stationarity, co-integration; Error correction mechanism, and ordinary least squares technique with the help of E-view econometric package of 3.0 models. The use of the log-linear method improves the validity of the estimates. This method also reduces, if not completely removes the heteroscedasticity 
errors, which may result from unscaled magnitudes on both sides of the equation (Amachi and Osaro, 2000; Ekpo, 1997 and Friend \& Puckett, 1994).

\section{Empirical Results}

\subsection{Empirical Results of the Unit Root Test}

The Augmented Dickey-Fuller (ADF) and Philip Perron (PP) formulae were employed to test for stationarity or the existence of unit roots in the data. The test results are as presented in appendix $1 \& 2$ shows that there is stationarity in the variables at first difference but not at level.

\subsection{Empirical Results of the Johansen Co Integration Test}

The result of our co-integration test revealed that there is a long run relationship between the power sector output and the explanatory variables. Firstly, the summary of the Johansen Co-integration Test is shown in the appendix 3. The model with lag 1 was chosen with the linear deterministic test assumption. The Johansen co-integration test is for the following series; PSO, INFDI, OUTFDI, NETFDI, OPEN, INFR, and INF.

\subsection{Empirical Results of the Error Correction Mechanism (ECM)}

As noted, the ECM is meant to tie the short-run dynamics of the co integrating equations to their long-run static dispositions. ECM test is used in testing the relationship between FDI Outward and power sector output while t-test is used in testing the effect of inward and net foreign direct investment on power sector output in Nigeria. Judging from the ECM coefficient as shown in the appendix 4 , it is observed to be negative implying that it is significant and approximately more than or equals to $67 \%(-0.673793)$. However, the p-value of the t-statistics of FDI Outward (OUTFDI) is 0.0003 implying that it is less than $5 \%$ level of significance. Thus, the null hypothesis of the effect of FDI inward on power sector is rejected while the alternative is accepted. More so, the t-value of the regression coefficient of FDI inward (INFDI) is statistically significant. This is confirmed by the p-value $(0.0000)$ which is less than $5 \%$ level of significance. Therefore, all the null hypotheses are rejected. Hence the acceptance of the alternative hypotheses.

\subsection{Major Findings}

The principal objective of this study was to determine the impact of FDI flow in Nigeria power sector from 2000 to 2011 . The result indicated that, most of the variables used were significantly related to the power sector output of the country. From the analysis of our study it was found that Foreign Direct Investment as macro economic variables as well as openness to trade; infrastructural development; inflationary rate had a significant influence on power sector in Nigeria.

\section{Summary of Finding, Conclusion and Recommendations}

This is the concluding section of this research work. Here, the major findings on this study were summarized and conclusions were made. Recommendations were also offered. 


\subsection{Findings}

In this study, our major task was to empirically investigate the impact of Foreign Direct Investment (FDI) flow on power sector in Nigeria. The empirical model was developed in the light of development in the methodology econometric modeling using Error correction technique of estimation and the analysis of time series data spanning from 2000-2011.

Generally, the empirical findings suggest that the equation of the PSO model as reflected in the coefficient of determination $\left(\mathrm{R}^{2}\right)$ and F-statistic is quite high and statistically significant as about $0.722394(72 \%)$ of the explanatory variables were explained at the long run. This means that $28 \%$ percent were unexplained. Variables such as; Net FDI; Out FDI were not statistically significant as their coefficients possess a negative sign. This is unlike Inward FDI; Openness to trade; infrastructural development and inflation which have positive effect and are statistically significant with the endogenous variable. The value of Durbin-Watson statistic is approximately 1.9, which shows that there is little or no auto-correlation among the variables. Thus, the overall estimates presented in this study suggest that an increase in net FDI inflow will bring about a rise in power sector output in Nigeria. We also discovered that FDI flow in Nigeria have a significant effect on power sector of the Nation.

\subsection{Conclusion}

Attraction of FDI is particularly an important policy issue for Nigeria government. In the context of their efforts to increase electricity power generation in the country, the country open bid for privatization of power sector and lay greater emphasis on attracting FDI by improving the overall enabling power sector and by putting in place specific incentives for such investment.

However, the need to enhance the current trend of FDI inflows to Nigerian economy becomes necessary. Thus, while the need for FDI is sharp, it does not justify using any incentive instrument particularly that which might fragment the tax system and undermine the macroeconomic policy stance. In fact, there is a wide range of positive incentives and policies available for Nigeria government to enhance inflow of FDI, the effectiveness of which would be facilitated by improving the enabling investment environment through sound macroeconomic policies, strengthened institutions intensification of structural reforms, rapid liberalization and regulation of markets, and privatization of economic activities. As progress is made on these issues, there will be less need for Nigeria government to resort to negative incentives and policies for attracting FDI, which not only undermine fiscal, financial and balance of payment (BOP) structures but also tend to attract the less productive type of FDI. More importantly, greater cooperation and harmonization in less developed countries such as Nigeria would assist in this regard by creating an attractive overall environment for longer term developmental FDI, which can contribute significantly to attaining the growth and development of the Nigerian economy. Power sector is very important to the health and well-being of Nigerians. There are several reasons for this. Electricity power supply brings about a higher standard of living: the quality of life based on the possession of necessities and luxuries which make life easier. 


\subsection{Recommendations}

From the analysis so far and the benefit of power sector, it can be argued that the policy issues drawn from this study may be large. In order to reap the benefit of this study, the researcher is of the view that the following recommendations be put forward;

1. FDI in Nigeria induces the nation's power sector growth. Although the overall effect of FDI on the whole economy may not be significant, the components of FDI positively affect power sector and therefore FDI needs to be encouraged.

2. Since FDI has the highest potential for contributing growth, it needs to be properly channeled and integrated into the mainstream of the nation's power sector.

3. The negative contribution of the manufacturing sector is a reflection of Nigerian's power sector poor output. There is need to consciously improve the level of electricity power supply to enable manufacturing sector to contribute positively to growth of Nigerian economy.

4. FDI should focus more on Nigeria's power sector because of the strategic relevance of the sector to the nation's economy. This will mitigate capital (fund) constraints faced by the key actors in the power sector of Nigeria's economy.

5. Concerted effort should be made by the government, stakeholders and NGOs to enhance the growth rate of Nigerian power sector. This will make the power sector more attractive to foreign investors, encourage production and generate employment especially for the rural populace.

\section{References}

Adelegan, J.O. (2000). Foreign direct investment and Economic Growth in Sub-Africa: A seemingly unrelated model. African Review of Money, Finance and Banking, Supplementary issue of "Savings and Development" 2000,525. Milan, Italy.

Adeolu, B.A. (2007). Foreign Direct Investment and Economic Growth: Evidence from Nigeria. Department of Agricultural Economics, Obafemi Awolowo University, Ile-Ife, Nigeria. AERC Research Paper 165, African Economic Research Consortium, Nairobi.

Akinkugbe, E. (2003). The determinants of foreign direct investment in Subhara African " Journal of Economy and finance, 20(11), 7-19.

Akinlo, A.E. (2004). Foreign direct investment and growth in Nigeria: An Empirical Investigation. Journal of Policy Modeling, 26(1), 627-39. http://dx.doi.org/10.1016/j.jpolmod.2004.04.011

Akpan H. E. (1997). Foreign Direct Investment in Nigeria. Central Bank Financial and Economic Review, 35(1), 22 - 34.

Alfaro, L., Chanda, S., Kalemli, O., \& Sayek, S (2003). Foreign Direct Investment and Economic Growth: The Role of Local Markets. Journal of International Economics, 11(3), 23-27. 
Amadi, S. N., \& Osaro, O. (2000). Security Pricing and Nigerian Capital Market. African Journal of Business and Economic Research, 1(1), 35.

Andreas J. (2007). Effects of FDI Inflows on Host Country Economic Growth. Journal of investment, 34(2), 23-4.

Anyanwu, J.C. (2004). An Economic Investigations of the Determinants of Foreign Direct Investment in Nigeria. Proceedings of the 1988 NES Annual Conference, 219-241. Lagos.

Aseidu, E. (2001). On the Determinants of FDI to Developing Countries. Is Africa Different? World Development, 30(1), 107-119. http://dx.doi.org/10.1016/S0305-750X(01)00100-0

Aseidu, E. (2009). Foreign Direct Investment in Africa: The Role of Natural Resources, Market, Government Policy, Institutions and Instability. United Nations University, World Institute for Development Economic Research. Research paper No. 2005/24, 1- 15.

Asiedu, E. (2004). Capital controls and foreign direct investment. World Development, 32(3), 479-90. http://dx.doi.org/10.1016/j.worlddev.2003.06.016

Asiedu, E. (2002). Determinant of Foreign Direct Investment in Developing Countries. World Development, 32(3), 479-90. http://dx.doi.org/10.1016/j.worlddev.2003.06.016

Battle, G. (2009). Foreign Direct Investment in Nigeria's service sector. Proceedings of the $12^{\text {th }}$ Annual Conference of the Regional Research Units of the Central Bank of Nigeria, 227-236.

Bengos, M., \& Sanchez-Robles, B. (2008). Foreign direct investment, economic freedom and growth: New evidence from Latin America. European Journal of Political Economy, 19(3), 529-545. http://dx.doi.org/10.1016/S0176-2680(03)00011-9

David, M. (2008). Concept and practice of Foreign direct investment. European journal of Economy and Finance, 34(23), 27-30.

David. M. (2009). Foreign Direct Investment Policies around the world. American Journal of Investment, 29(3),39-40.

De-Gregorio, J. (2003). The Role of FDI and Natural Resources in Economic Development. Working paper No 196. Central Bank of Chile, Santiago.

Ekpo, A .H. (2003). Foreign Direct Investment in Nigeria: Evidence from Time Series Data. CBN Economic \& Financial Review, 35(1), 59- 78. Abuja.

Electric Power Sector Reform (EPSR) Act. (2005).

Feldstein, M. (2008). Aspects of the Global Economic Integration: Outlook for the Future. Cambridge, Massachusetts: NBER Working Paper No. 7(89), 12-14.

Friend, I., \& Puckett, M. (1964). Dividend and Stock Prices. American Economic Review, pp. 20.

Gnansonuou, E. (2008). Boosting the electricity sector in West Africa: An integrative Vision. 
International Association of Energy Economies, third quarter.

Hymer, S. (1976). Industrialization Theory on FDI and Spillover Effects. Econometric, 34-34.

Jerome, A., \& J. Ogunkola (2004). FDI in Nigeria: Magnitude, Direction and Prospects. Paper presented to the African Economic Research Consortium. Special Seminar Series. Nairobi. Poverty Alleviation CRERS.

Kiely, G. (2007). Transnational Corporations and the capital investment. Journal of International Economics, 14(3), 23-45.

Mojekwu, J. N., \& Samson, O. (2012). Foreign Direct Investment and the challenges of sustainable development in Nigeria. Journal of Research in International Business and Management, 2(7), 190-198.

Morriset. J. (2001). Administrative Barriers to Foreign Direct Investment in Developing Countries. World Bank Research Working Paper 2848, 3-24. Review, 43, 335-356. Washington DC.

Obwona, M. (2004). Foreign Direct Investment (FDI) in Africa. Financing Pro poor GROWTH in Africa AERC Senior Policy Seminar. VI-Seminar papers, 60-94.

Odozi, V.A. (1995). An Overview of Foreign Investment in Nigeria 1960- 1995. Occasional Paper No. 11. Research Department, Central Bank of Nigeria.

OECD. (2011). Benchmark Definition of Foreign Direct Investment. Paris OECD, 4, 34-9.

Ogbanje, E. C., Okwu, O. J., \& Saror, S. F. (2010). An analysis of Foreign Direct Investment in Nigeria: The Fate of Nigeria's Agricultural Sector. A Publication of Nasarawa State University. Keffi, 6(2), 15-25.

Oke, Y. (2011). Beyond power sector reforms: The need for decentralized energy options for electricity governance in Nigeria. International Journal of Business Administration, 4(2), 34-54.

Opaluwa, D., Ameh, A. A., Alabi, J. O., \& Abdul, M. (2012). The effect of Foreign Direct Investment on Nigeria Manufacturing Sector. International Journal of Business and Management, 4(2), 140-148.

Raul, D. N. (2012). Impact of foreign direct investment (FDI) on the growth of Nigerian economy. The International Trade Journal of Administration, 7(4), 655-672.

Renewable Electricity Policy of the Federal Government of Nigeria. (2006). 


\section{Appendix 1. Augmented Dickey Fuller Unit Root Test}

Trend and Intercept

\begin{tabular}{lcrrrc} 
Series & ADF Test Statistic & $5 \% \mathrm{cv}$ & & $10 \% \mathrm{cv}$ & Order Remarks \\
\hline PSO & -5.574606 & -3.6219 & -3.2474 & $1(1)$ & Stationary \\
INFDI & -4.747655 & -3.6219 & -3.2474 & $1(1)$ & Stationary \\
OUTFDI & -8.778954 & -3.6219 & -3.2474 & $1(1)$ & Stationary \\
NETFDI & -5.289252 & -3.6219 & -3.2474 & $1(1)$ & Stationary \\
OPEN & -13.69273 & -3.6219 & -3.2474 & $1(1)$ & Stationary \\
INFR & -6.596387 & -3.6219 & -3.2474 & $1(1)$ & Stationary \\
INF & -7.181128 & -3.6219 & -3.2474 & $1(1)$ & Stationary
\end{tabular}

Source: E-view 3.0

\section{Appendix 2. Phillips-Perron Unit Root Test}

Trend and Intercept

$\begin{array}{llllll}\text { Series } & \text { PP Test Statistic } & 5 \% \mathrm{cv} & 10 \% \mathrm{cv} & \text { Order } & \text { Remarks } \\ \text { PSO } & -5.770594 & -3.6219 & -3.2474 & 1(1) & \text { Stationary } \\ \text { INFDI } & -4.844718 & -3.6219 & -3.2474 & 1(1) & \text { Stationary } \\ \text { OUTFDI } & -13.67840 & -3.6219 & -3.2474 & 1(1) & \text { Stationary } \\ \text { NETFDI } & -5.491613 & -3.6330 & -3.2535 & 1(1) & \text { Stationary } \\ \text { OPEN } & -18.66058 & -3.6219 & -3.2474 & 1(1) & \text { Stationary } \\ \text { INFR } & -6.888977 & -3.6219 & -3.2474 & 1(1) & \text { Stationary } \\ \text { INF } & -8.037032 & -3.6219 & -3.2474 & 1(1) & \text { Stationary }\end{array}$

Source: E-view 3.0

Appendix 3. Co-integration test

\begin{tabular}{|c|c|c|c|c|}
\hline \multirow[t]{2}{*}{ Eigenvalue } & \multirow[t]{2}{*}{ Likelihood Ratio } & \multicolumn{2}{|c|}{$5 \% \mathrm{cv}$} & \multirow[t]{2}{*}{$1 \% \mathrm{cv}$} \\
\hline & & esized I & & \\
\hline .997091 & 285.7730 & 94.15 & 103.18 & None ** \\
\hline .949575 & 163.1329 & 68.52 & 76.07 & At most $1 * *$ \\
\hline .857624 & 100.4001 & 47.21 & 54.46 & At most $2 * *$ \\
\hline .775524 & 59.46515 & 29.68 & 35.65 & At most $3 * *$ \\
\hline .689321 & 31.75493 & 18.73 & 22.41 & At most $4 * *$ \\
\hline .592319 & 28.09147 & 15.41 & 20.04 & At most $5 * *$ \\
\hline .356233 & 9.248795 & 3.76 & 6.65 & At most $6 * *$ \\
\hline
\end{tabular}

Source: E-view 3.0

$*(* *)$ denotes rejection of the hypothesis at $5 \%$ significance Level

L.R test indicates 7 cointegrating equation(s) at 5\% significance.

Normalized Cointegrating Coefficients: 1 cointegrating Equation(s) 
Appendix 4. Error Correction Model (ECM)

\begin{tabular}{lcccc} 
Variable & Coefficient & Std. Error & t-Statistic & Prob. \\
C & 2.980241 & 20.66824 & 0.144194 & 0.8874 \\
LOG(INFDI) & 1.961777 & 0.452107 & 4.339187 & 0.0005 \\
LOG(OUTFDI) & 7.882973 & 1.120916 & 7.032617 & 0.0003 \\
LOG(NETFDI) & $1.79 \mathrm{E}-07$ & 3.834127 & 3.466943 & 0.0007 \\
LOG(OPEN) & -39.86156 & 47.72296 & -0.835270 & 0.4176 \\
LOG(INFR) & 2.882365 & 6.917107 & 0.416701 & 0.6832 \\
LOG(INF) & -5.254368 & 2.379966 & 2.207749 & 0.0444 \\
ECM(-1) & -0.673793 & 0.101861 & -6.614821 & 0.0000 \\
R-squared & 0.722394 & Mean dependent var & 2.636364 \\
Adjusted R-squared & 0.683591 & S.D. dependent var & 113.1386 \\
S.E. of regression & 95.76154 & Akaike info criterion & 12.23689 \\
Sum squared resid & 128383.8 & Schwarz criterion & 12.63363 \\
Log likelihood & -126.6058 & F-statistic & 218.7554 \\
Durbin-Watson stat & 1.887745 & Prob(F-statistic) & 0.000000 \\
\hline
\end{tabular}

Source: E-view 3.0 